\title{
Nationwide Survey of Stool Culture Methods for the Diagnosis of Bacterial Gastroenteritis in Korea, 2016
}

Jung-Hyun Byun ${ }^{1}$, Soo In $\mathrm{Oh}^{2}$, Hyunwoong Park $^{2}$, Sunjoo Kim ${ }^{1}$, and Jeong-Hwan Shin ${ }^{3}$

${ }^{1}$ Department of Laboratory Medicine, Gyeongsang National University School of Medicine, Jinju; ${ }^{2}$ Department of Laboratory Medicine, Changwon Gyeongsang National University Hospital, Changwon; ${ }^{3}$ Department of Laboratory Medicine, Inje University Busan Paik Hospital, Busan, Korea

\section{Corresponding author:} Sunjoo Kim

Department of Laboratory Medicine, Gyeongsang National University School of Medicine, 79 Gangnam-ro, Jinju 52727, Korea

Tel: +82-55-214-3072

Fax: +82-55-214-3089

E-mail: sjkim8239@hanmail.net
Background: Stool cultures are essential for diagnosing bacterial gastrointestinal infections. Laboratory procedures and target organisms for stool culture testing can vary by institute. Therefore, a nationwide survey was conducted to determine the stool culture procedures performed in clinical laboratories of Korea.

Methods: Questionnaires were delivered by electronic mail to 98 clinical microbiologists and by Google survey to the 301 institutes participating in the Korean External Quality Control Program of Bacterial Cultures.

Results: Of the 68 institutes sent complete responses, Gram staining and wet smears were performed in $73.5 \%$ and $64.7 \%$, respectively. A molecular test was conducted in $32.4 \%$ of laboratories, and blood agar plates were used in $23.5 \%$. Staphylococcus aureus, Pseudomonas aeruginosa, and Candida species were reported for predominant growth by $17.6 \%, 8.8 \%$, and $7.4 \%$ of the respondents, respectively. Campylobacter culture was available only in $25.0 \%$ of laboratories, whereas Clostridium difficile could be cultivated in $38.2 \%$. Susceptibility testing results of Salmonella-Shigella were reported for all tested antibiotics in $22.1 \%$ of laboratories, whereas $69.1 \%$ reported results for antibiotics specified by the Clinical and Laboratory Standard Institute guidelines.

Conclusions: Methods and results of gram staining, wet smears, use of stool culture media, target microorganisms, and antibiotic susceptibility differed among the institutes. Further discussion is needed to develop a standardized protocol for stool culture to maximize isolation of bacterial pathogens that cause gastroenteritis.

(J Lab Med Qual Assur 2017;39:23-30)

Key Words: Gastrointestinal, Diarrhea, Practice guideline, Surveys

\section{서론}

위장관염은 매우 흔한 감염질환으로 특히 저개발국가에서 는 영유아 사망의 주요 원인 중 하나이다[1-3]. 위장관염을 유 발하는 주요 세균으로는 임상미생물검사실에서 분리되는 가 장 흔한 원인균인 Salmonella와 Shigella뿐만 아니라 여름철 오염된 해산물에 의한 Vibrio, 가금류에 의한 Campylobacter, 혈변을 일으키며 용혈성요독증을 유발할 수 있는 Escherichia coli O157:H7, 우하복부 통증을 잘 일으키는 Yersinia 등 다양 하다[4]. 특히 최근에는 항균제 치료를 받은 환자에서 설사를 일으키는 Clostridium difficile이 위장관염의 중요 원인균으로 대두하였다[5]. 이러한 세균들은 주로 염증성 설사를 일으키 는데, 독소에 의한 비염증성 설사를 일으키는 Staphylococcus aureus, Clostridium perfringens, Clostridium botulinum, Bacillus cereus, Vibrio cholerae 등과는 임상양상에 차이가 있다[3,4,6]. 
특히 최근에는 분자생물학적 방법을 이용한 검사가 도입되 면서 전통적인 배양방법에 비해 검출률이 2-4배 증가하였다고 보고되었다[7-9]. 과거에는 배양하기 까다로워 진단이 어려웠 던 병원성 대장균, Campylobacter와 일반적으로 배양하지 않 던 Aeromonas, Plesiomonas shigelloides, 혐기성 배양이 필 요한 C. perfringens 등의 검출 빈도가 증가하였다 $[7,8,10]$.

대변에는 정상적으로 세균이 다수 존재하므로 설사의 원인 균을 선택적으로 분리하는 것이 매우 어렵다. 대변배양은 다 른 검체에 비해서 배양조건이나 방법이 까다로우며 많은 종 류의 배지를 사용해야 하는 등 비용이 많이 드는 반면 검출률 은 낮은 특징이 있다[11]. 대변 검체의 그람염색은 다른 검체 의 그람염색과 달리 거의 모든 형태의 세균이 다 보이며 낮 은 민감도와 특이도로 인해 일상적인 검사로서 한계가 있으며 $\lceil 10,12]$, 염증성 설사에 한해 무염색 도말에서 백혈구를 관찰 하는 것이 임상적으로 유용하게 이용되고 있다 $[4,13,14]$.

대변배양의 양성률이 과거에 비해 현저히 낮아졌는데 이는 개인위생의 향상, 보건환경의 개선, 냉장고 보급 확대로 인한 적절한 음식물 보관 및 약수물 대신 생수 음용 등 다양한 원인 에 의한 것으로 추정할 수 있다. 하지만 해외여행의 증가, 외국 인의 유입 증가, 샐러드나 회 등 조리하지 않은 음식 섭취, 외 식, 집단 급식 등에 의해 여전히 세균성 위장관염에 노출될 위 험성이 존재하므로 지속적이 관심이 필요하다. 세균성 위장관 염 이외에도 rotavirus와 norovirus 등 바이러스성 설사와 $C$. difficile 독소에 의한 설사의 빈도가 상대적으로 더 증가하였다 $[7,8,15]$.

본 연구에서는 설문조사를 통하여 현재 국내에서 사용하고 있는 대변배양 검사방법의 실태를 조사하고, 그 결과를 바탕으 로 바람직한 대변배양검사의 권고안을 제시하고자 하였다.

\section{재료 및 방법}

임상미생물검사실이 있는 종합병원 및 3 차병원에 근무하 는 98 명의 진단검사의학과 전문의에게 이메일을 통하여 설문 지 파일을 발송하였다. 또한 대한임상검사정도관리협회의 세 균배양 외부정도관리 프로그램에 참여하고 있는 301군데의 의 료기관에 이메일을 통해 구글 설문을 보낸 후 직접 온라인에서 설문지에 입력하도록 하였다. 설문지 회신은 2016년 5월부터 7월까지 약 3개월간 시행하였다.

설문지는 크게 네 항목으로 작성하였다. 첫 번째 항목은 대 변 그람염색, 대변 백혈구를 관찰하기 위한 직접도말검사(wet smear), 분자유전검사의 시행, 대변의 질(묽기) 평가 등 일반 적인 사항으로 구성하였다. 두 번째 항목은 대변배양을 위해
사용하는 용기와 수송배지, 검사 지연 시 검체 보관, 부적합 검체에 대한 거절기준 등에 대한 질문으로 구성하였다. 세 번 째 항목은 배양을 시행하는 과정에 대한 문항으로, 검사실에 서 사용하는 증균배지, 평판배지, 배양온도 및 가스 등 배양조 건, Campylobacter나 E. coli O157, C. difficile 균을 분리하는 시설을 갖추고 있는지, C. difficile 집락 독소검사를 시행하는 지에 대해 질문하였다. 마지막 항목에서는 세균의 동정 및 감 수성검사, 배양결과 보고방법 및 의료 관련 감염 예방을 위한 vancomycin-resistant enterococci (VRE) 및 carbapenemresistant Enterobacteriaceae (CRE) 선별검사에 대한 질 문을 포함하였다. 통계처리는 IBM SPSS ver. 21.0 (IBM Corp., Armonk, NY, USA)을 이용하여 Pearson 카이제곱검 정으로 분석하였다.

\section{결과}

\section{1. 응답기관}

이메일로 회신한 곳은 50 기관(회신율 $51.0 \%$ )인 반면, 구글 설문 프로그램을 통하여 회신한 기관은 18 기관(회신율 $6.0 \%$ ) 으로 두 방법 간에 차이가 컸다 $(P<0.0001)$. 지역별로는 서울 20 기관, 경기도 14 기관, 경상도 8 기관, 부산 6 기관 순이었다. 병상 수별로는 100-400병상이 18기관(26.5\%), 401-800병상 이 22기관(32.4\%), 801 병상 이상이 24기관(35.3\%), 기타 4기 관이었다.

\section{2. 검체 용기, 염색 및 대변 질 평가}

모든 대변 검체에 대해서 그람염색을 시행하는 기관은 $14.7 \%$ (10/68), 임상에서 의뢰되는 경우에만 시행하는 기관 이 58.8\% (40/68)였고, 나머지 26.5\% (18/68)는 그람염색을 시행하지 않았다(Table 1). 그람염색에서 관찰되는 모든 세 균을 보고하는 비율은 $66.0 \%$ (33/50), 우세한 세균만 보고하 는 비율은 16.0\% (8/50)였고 12.0\% (6/50)는 백혈구 존재 유 무만 보고하였다. 직접도말검사는 $64.7 \%$ (44/68)에서 시행하 고 있었다. 직접도말검사는 모두 대변에 생리식염수를 한 방 울 떨어뜨려 현미경 관찰하는 방법을 사용하고 있었다. 세균 배양 이외에 추가적으로 분자생물학적 방법을 이용하는 기관 은 32.4\% (22/68)였는데, 3기관은 2가지의 제품을 사용하고 있었다. 대변의 고형 여부를 구분하여 보고하는 기관은 $4.4 \%$ (3/68)에 불과하였으며, 대다수 기관은 대변의 질 평가를 시행 하고 있지 않았다. 


\section{Journal of LABORATORY MEDICINE and QUALITY ASSURANCE}

\section{Jung-Hyun Byun et al • Nationwide Survey of Stool Culture Methods}

Table 1. Positive responses to questions regarding stool culture procedures from 68 institutes

\begin{tabular}{lc}
\hline \multicolumn{1}{c}{ Stool culture procedures performed } & No. (\%) \\
\hline Gram staining & $50(73.5)$ \\
Gram staining of all specimens & $10(14.7)$ \\
Gram staining only as requested & $40(58.8)$ \\
Wet smear & $44(64.7)$ \\
Molecular detection & $22(32.4)$ \\
Report on stool quality (e.g., formed or loose) & $3(4.4)$ \\
Transport media & $6(8.8)$ \\
Routine use of blood agar plate & $16(23.5)$ \\
Report of pure growth of Staphylococcus aureus & $12(17.6)$ \\
Report of pure growth of Pseudomonas aeruginosa & $6(8.8)$ \\
Report of pure growth of yeast & $5(7.4)$ \\
Ability to culture Campylobacter spp. & $17(25.0)$ \\
Ability to culture Escherichia coli O157 & $42(61.7)$ \\
Ability to culture Clostridium difficile & $26(38.2)$ \\
Vancomycin-resistant enterococci surveillance & $54(79.4)$ \\
Carbapenem-resistant Enterobacteriaceae surveillance & $28(41.2)$ \\
\hline
\end{tabular}

\section{3. 대변배양 일상검사}

직접 대변 검체를 운송하는 기관은 $91.2 \%$ (62/68)으로 거 의 대부분을 차지하고 있었고 수송배지를 이용하여 운송하는 기관이 5.9\% (4/68), 대변과 수송배지를 동시에 사용하는 기 관이 2.9\% (2/68)이었다. Selenite-F 증균 액체배지를 사용하 는 기관은 26.5\% (18/68)였으며, Gram-negative (GN) 증균 액체배지를 사용하는 기관은 $2.9 \%$ (2/68)에 불과하였다.

대변배양검사에 일상적으로 사용하는 배지로는 MacConkey 한천(97.1\%)과 Salmonella-Shigella (SS) 한천(89.7\%)이 가 장 흔하였다. Thiosulfate citrate bile sucrose (TCBS) 배지 를 5-10월 사이에 사용하는 기관은 55.9\%였고, 1년 내내 사 용하는 기관은 $5.9 \%$ 였으며, $4.4 \%$ 는 사용하지 않았다(Table 2). 혈액 한천배지를 일상적으로 사용하는 기관은 $23.5 \%$ 였 으며, xylose-lysine-desoxycholate (XLD) 한천(11.8\%)이나 Hektoen enteric $(\mathrm{HE})$ 한천 $(2.9 \%)$ 을 사용하는 기관은 드물 었다. 한천배지의 조합으로는 응답한 58기관 중 MacConkey, $\mathrm{SS}, \mathrm{TCBS}$ 배지를 사용하는 기관이 $48.3 \%$ 로 가장 많았고, MacConkey, SS 배지를 사용하는 기관이 $20.7 \%$ 이었다. 배양 온도는 응답한 64 기관 중 $35^{\circ} \mathrm{C}$ 가 $32.8 \%, 36^{\circ} \mathrm{C}$ 가 $18.8 \%, 37^{\circ} \mathrm{C}$ 가 $40.6 \%$ 를 차지하였다. 배양시간은 응답한 60 기관 중 18 시간 혹은 $18-24$ 시간이 $30.0 \%, 24$ 시간이 $46.7 \%, 48$ 시간이 $18.3 \%$ 를 차지하였다. 배양가스는 응답한 61 기관 중 $49.2 \%$ 가 $\mathrm{CO}_{2}$ 를 사용하였고, 나머지 $50.8 \%$ 는 공기를 사용하였다.
Table 2. Culture media routinely used for stool culture, and drug susceptibility reporting for Salmonella-Shigella in 68 institutes

\begin{tabular}{lc}
\hline Culture media used and drug susceptibility reporting & No. $(\%)$ \\
\hline Enrichment broth & $18(26.5)$ \\
Selenite-F & $2(2.9)$ \\
Gram-negative & $16(23.5)$ \\
Agar plate & $66(97.1)$ \\
Blood agar & $61(89.7)$ \\
MacConkey & $8(11.8)$ \\
$\begin{array}{l}\text { Salmonella-Shigella } \\
\text { Xylose-lysine-desoxycholate }\end{array}$ & $2(2.9)$ \\
$\begin{array}{l}\text { Hektoen enteric } \\
\text { Thiosulfate citrate bile sucrose }\end{array}$ & $46(67.6)$ \\
$\begin{array}{l}\text { Salmonella-Shigella spp. drug susceptibility reporting } \\
\begin{array}{l}\text { Automated testing and susceptibility reporting only } \\
\text { for drugs recommended by CLSI }\end{array}\end{array}$ & $39(57.4)$ \\
$\begin{array}{l}\text { Susceptibility reporting for all drugs subjected to } \\
\text { automated testing with CLSI comment }\end{array}$ & $6(8.8)$ \\
$\begin{array}{l}\text { Susceptibility reporting for all drugs subjected to } \\
\text { automated testing without comment }\end{array}$ & $15(22.1)$ \\
$\begin{array}{l}\text { Testing by the disk diffusion method and } \\
\text { susceptibility reporting only for drugs } \\
\text { recommended by CLSI }\end{array}$ & $8(11.8)$ \\
\hline
\end{tabular}

Abbreviation: CLSI, Clinical and Laboratory Standards Institute. *Thiosulfate citrate bile sucrose medium is used selectively from May to October in $55.9 \%$ of the laboratories surveyed.

\section{4. 까다로운 세균분리}

Campylobacter를 분리할 수 있는 시설을 갖추고 있는 곳 은 25.0\% (17/68)에 불과하였다. 대부분 주치의가 의뢰한 경 우, 그람염색에서 이 세균이 의심되는 경우, 혹은 대변이 무르 거나 설사변인 경우에 Campylobacter를 배양하였다. E. coli O157을 분리할 수 있는 기관은 61.7\% (42/68)로 비교적 많은 편이었고, 대부분은 주치의가 의뢰하는 경우에만 시행하였다. E. coli $\mathrm{O} 157$ 동정방법은 질병관리본부에서 공급하는 항혈청 을 이용하는 경우가 $80.4 \%$ 로 가장 많았다. 황색포도알균이 순 수하게 증식한 경우 양성으로 보고하는 비율 $(17.6 \%, 12 / 68)$ 은 녹농균(8.8\%, 6/68)이나 효모균 $(7.4 \%, 5 / 68)$ 이 순수하게 증식한 경우 양성으로 보고하는 비율보다 약간 높았으나 통 계적으로 유의하지는 않았다 $(P=0.122)$. C. difficile을 배양 하는 기관은 $38.2 \%$ (26/68)였고, 배지는 상품화된 발색배지 (예, ChromID CD Agar; bioMerieux Inc., Marcy-l'Etoile, France) $(75 \%, 15 / 20)$ 혹은 Clostridium difficile selective agar (Becton Dickinson, Sparks, MD, USA) (20\%, 4/20) 를 주로 사용하였으며, 알코올로 대변 전처리를 하는 비율은 
$53.8 \%$ (14/26)였다. 한 기관에서는 별도의 의뢰코드를 사용 하지 않고, 모든 대변에 대해서 C. difficile을 배양하고 있었다. 균의 독소생성 여부까지 보고하는 기관은 $23.1 \%$ (6/26)에 불 과하였다.

$\mathrm{VRE}$ 감시배양기관은 $79.4 \%$ (54/68)로 매우 높았지만, $\mathrm{CRE}$ 감시배양기관은 $41.2 \%$ (28/68)로 약 절반이었다. 감시 배양대상은 주로 중환자실에 입실하는 환자나 이전에 VRE나 $\mathrm{CRE}$ 가 분리된 환자를 대상으로 하였고, 방법은 주로 상품화 된 배지를 구입하여 사용하였다(자료 미제시). 한 기관에서는 모든 입원환자에 대해서 VRE 선별검사를 시행하고 있었다.

\section{5. 항균제 감수성검사}

Salmonella나 Shigella가 분리된 경우 대부분은 자동화장 비를 이용하여 항균제 감수성검사를 시행하고 있었다. 자동화 장비로 항균제 감수성검사를 시행한 후 보고하는 방법은 다 양하였는데, 'Clinical and Laboratory Standards Institute (CLSI)에서 권장하는 항균제만 보고한다'는 기관이 $57.4 \%$ (39/68)로 가장 많았다. 모든 항균제 감수성결과를 보고하되 CLSI 지침[16]에 따른 약제에 대해서 코멘트로 보고하는 기 관은 8.8\% (6/68)였고, CLSI 코멘트를 첨부하지 않고 검사 한 모든 약제에 대한 결과를 보고하는 기관이 $22.1 \%$ (15/68) 였다. 나머지는 디스크확산법으로 CLSI에서 추천하는 약제에 대해서만 검사하여 보고하였다( $11.8 \%, 8 / 68)$.

\section{고찰}

이메일 회신율은 51.0\% (50/98)인 반면 구글 설문 회신율 은 6.0\% (18/301)로 이메일 회신율이 훨씬 높았다. 이는 이메 일로 임상미생물을 전공하는 전문의에게 먼저 자료를 요청한 후, 구글 설문지는 약 1 개월 후 임상미생물 담당자에게 배포되 었기 때문으로 판단된다. 또한 구글 설문은 입력하기 쉬운 장 점이 있지만 이메일 설문지 파일보다는 자세하게 문항을 표현 하지 못하는 단점이 있었다.

대변 검체에서 그람염색을 시행하는 기관은 $73.5 \%$ 로 비교 적 많았지만 그 효용성은 제한적이다. 특히 대변에는 정상적으 로 상재균이 다수 존재하므로, 보이는 세균을 모두 보고한다 면 별 의미가 없을 수 있다. 따라서 한두 가지 세균만 순수하게 보이거나 백혈구가 관찰될 경우 이를 보고하는 것이 더 바람 직할 것으로 판단한다[3]. 특징적으로 구불구불한 그람음성간 균이 관찰되는 경우 Campylobacter나 Vibrio를 의심할 수 있 어 도움을 받을 수 있다[3,17]. 직접도말검사를 시행하는 기관 도 $64.7 \%$ 로 많았다. 배양결과가 2-3일 걸리는 것을 감안하면,
직접도말검사는 그 결과를 신속하게 판정할 수 있는 장점이 있 는 반면 많은 숙련도가 필요한 검사이다[3]. 통상 methylene blue 염색방법을 사용하도록 권장하고 있지만[3,17], 우리나 라에서는 대부분 생리식염수를 이용한 무염색도말검사를 사 용하고 있다. 직접도말검사에서는 백혈구뿐만 아니라 적혈구 도 관찰할 수 있어 혈변 여부를 판정할 수 있다. 또한 세균에 따라서는 백혈구나 적혈구 한 가지만 관찰되는 경우가 있어, 직접도말검사가 세균 추정에 도움을 줄 수 있다[18]. 하지만 염증성 설사에서도 백혈구가 보이지 않을 수 있고, 반대로 비 염증성 설사에도 백혈구가 관찰될 수 있어서 직접도말검사 한 가지로만 염증성 설사를 진단할 수는 없다 $[10,17,19]$. 실제로 국내 한 보고에서는 응급실에 설사를 주소로 내원한 환자에 대 한 항균제 치료 여부의 판단근거로 의사들은 대변 백혈구 유무 나 세균배양결과보다는 발열이나 복통 등 임상양상에 더 의존 한다고 하였다[19].

분자유전학적 검사법이 발달하면서 대변에서 바이러스, 세 균 및 기생충을 한 번에 검출할 수 있는 방법들이 소개되었는 데, 현재 $32.4 \%$ 의 기관이 이 방법을 사용하고 있었으며, (주) 씨젠의 Seeplex Diarrhea ACE Detection (Seegene, Seoul, Korea) 제품을 사용하는 기관이 가장 많았다(자료 미제시). 이 제품에 대한 임상평가는 몇 번 보고된 바 있는데, 배양에 비하여 검출률이 높으며 특히 배양이 까다로운 병원성 대장 균, Campylobacter, Aeromonas, C. perfringens 등의 빈도 가 높게 나타났다 $[7,8,10]$. 또한 다중검사이므로 두세 가지 원 인체가 동시에 검출되는 중복감염이 9.3\%-23.2\%로 보고되어 $\lceil 7,8,15]$, 이에 대한 해석과 단일 균종과 비교한 임상적 특성, 치료방침에 대한 새로운 이슈가 도출되었다 $[9,15]$.

대변의 고형 여부와 균주 분리율과는 무관하다는 보고가 있 지만[12], 저자들은 대변의 질을 관찰하여 설명해 주는 것이 주치의에게 도움을 줄 것으로 판단한다. 대개 환자가 직접 검 체를 채취하므로 주치의는 대변의 형태를 관찰하지 않고 환자 의 설명에 의존하게 되므로 정확하지 않을 수 있다. 즉 검사실 에서 대변상태를 관찰하여 수양성인지, 묽은 변인지, 고형 변 인지 구분하고[5], 또한 점액성인지 혈변인지 기술하면 위장 관염을 분류하는 데 도움이 될 것으로 생각한다[18,20].

검사 지연 시 대부분 검체를 냉장 보관하고 있었다. 하지 만 기존의 검은 색 조그만 대변용기는 과거 기생충검사를 위 한 용기로 시작하게 되었는데 아직도 많은 기관에서 대변배 양에 이용하고 있었다. 이것은 설사변의 경우 받기도 쉽지 않 고 또한 뚜껑이 헐거우면 대변이 흐를 가능성도 있으며 무균 용기가 아니므로 적절하지 않다. 요 또는 객담 검체에 사용하 는 무균 배양용기는 사이즈도 크고, 뚜껑이 나사모양으로 되 
어 있어 대변배양용기로 적합하다. 수송배지를 사용하는 기 관은 6 군데 $(8.8 \%)$ 로 매우 적었는데 대변 검체를 직접 사용하 는 경우 이들 검체는 2 시간 이내에 한천배지에 접종이 되어 야 한다 $[17,18]$. 입원한 환자의 경우 업무의 흐름상 2 시간 이 내에 검체를 접종하는 것이 쉽지 않으므로, 향후 Cary-Blair 나 Stuart 수송배지의 유용성에 대한 검토가 필요해 보인다. 또한 환자가 편하게 대변 검체를 채취할 수 있는 방법을 강구 해야 할 것이다[11,18]. 대변 검체 접종이 2 시간 이상 지연되 는 경우 반드시 냉장 보관하는 것이 필요하다. 다만 이 경우 Shigella는 냉장온도에서 쉽게 사멸하므로[3,17], 이 균이 의 심되는 경우에는 대변을 바로 접종하거나 $\mathrm{GN}$ 증균배지를 사 용하는 것이 필요할 것으로 판단한다.

액체 증균배지의 사용기관도 Selenite-F $26.5 \%, \mathrm{GN}$ 액 체배지 $2.9 \%$ 로 매우 낮았는데, 이 또한 반드시 대변배양 에 필요한 것으로 판단한다. Lee [21]가 보고한 바에 의하면 Selenite-F를 추가한 경우에만 Salmonella 균이 분리된 비율 이 $22 \%$ 로, 액체 증균배지를 반드시 사용해야 하고 경제성을 고려한다면 차라리 한천배지 한 가지를 빼는 것이 좋다고 하였 다. Ko 등[22]도 설사의 원인균에 대한 실험실적 연구에서 한 천배지에서만 자라는 비율보다는 증균배지 접종 후 한천배지 에 접종하는 것이 효율적이라는 것을 보고한 바 있으며, 일반 적으로 알려진 것과는 달리 Selenite-F는 8시간, GN 액체배 지는 2 시간만 증균하는 것이 균 검출률이 가장 높다고 하였다. Selenite-F는 Shigella를 억제한다고 알려져 있다[17,18].

대변배양검사에 사용하는 배지로는 MacConkey, SS 한천 을 가장 많이 사용하였고, 약 절반에서 TCBS 배지를 추가하 였다. 기타 XLD나 $\mathrm{HE}$ 배지는 매우 드물게 사용하고 있었다. MacConkey 배지는 감별배지로서 반드시 사용해야 하지만, 1 차 배지로 주로 사용하는 SS 한천은 Shigella 분리가 어려운 경우가 있고, $\mathrm{XLD}$ 나 $\mathrm{HE}$ 에 비해서 세균 억제효과가 큰 단점 이 있다[13,18]. 혈액한천은 $23.5 \%$ 에서만 1 차 배지로 사용하 고 있었는데, 지침에는 혈액한천을 1 차 배지로 사용할 것을 권 고하고 있다[3,17,18]. 그 이유로는 완전용혈을 보이는 Vibrio, Aeromonas, P. shigelloides 등 oxidase 양성 그람음성간균 분리 가능성이 높아지고, 또한 항균제 사용자에서 황색포도알 균, 효모균, 녹농균의 분리가 용이하다는 점 때문이다[18]. 이 들 균들은 항균제연관 설사를 일으킬 수 있다[23]. 배양온도는 $35^{\circ} \mathrm{C}-37^{\circ} \mathrm{C}$ 로 다양하였는데 모두 적합한 것으로 판단하고, 배 양시간은 24시간(46.7\%)이 적합하지만, 48시간으로 응답한 기관도 $18.3 \%$ 였다. 배양가스의 경우 공기를 사용하도록 권장 하고 있지만[18], $\mathrm{CO}_{2}$ 를 사용하는 기관도 약 절반에 달하였다.

Campylobacter를 분리할 수 있는 시설을 갖춘 곳은 $25.0 \%$
에 불과하였다. 이는 이 세균을 분리하는 특수배지나 미호기성 가스, 특히 $42^{\circ} \mathrm{C}$ 배양기가 필요하다는 여러 가지 제한점과 동 정이 어렵기 때문일 것으로 판단한다. 하지만 이 균은 가금류, 계란, 우유, 과일, 샐러드 등 여러 경로를 통해 인체 감염을 일 으킬 수 있고, 많은 지침에서도 대변에서 반드시 배양이 필요 하다고 권장하는 만큼[11,18], 우리나라에서도 이 균에 대한 배양시설을 확보하는 것이 필요해 보이고, 모든 변에 대해서 시행하기보다는 무른 변이거나 혈변, 점액변, 주치의가 의뢰한 경우에 시행하는 것이 좋을 것으로 판단한다.

E. coli O157은 특징적으로 혈변을 일으키며, 직접도말검사 에서 적혈구는 관찰되지만 백혈구는 관찰되지 않는 특징이 있 다[18]. 임상적으로 중요한 점은 다른 원인균과는 달리 이 세 균은 항균제 치료가 금기이다[20]. 즉 항균제를 투여할 경우 오히려 shiga 독소 생산이 증가하여, 용혈로 인한 신장기능의 저해, 즉 용혈성 요독증이 생겨 소아의 신부전의 중요한 원인 이 될 수 있다[1,18]. 따라서 혈변의 경우 이 세균과 다른 세 균을 감별하는 것은 필요하고, 독소검사까지 시행해야 한다 $[9,11,13]$. 약 $62 \%$ 기관에서만 이 균의 분리가 가능하였는데, 이는 sorbitol-MacConkey 배지 준비, shiga 독소검사 등이 까 다롭기 때문으로 판단한다.

C. difficile을 배양하는 기관은 $38.2 \%$ 로 비교적 적었는데, 이는 특이도가 높은 독소검사로 대치할 수 있기 때문으로 판단 한다[23]. 다만 역학적 조사나 보균자검사, 항균제 내성패턴을 연구하기 위해서는 C. difficile 배양검사가 필요하며[18] 이 경 우 배양된 균주에서 독소를 생성하는지 여부를 판단해야 하지 만[18,24] 그 비율은 $23.1 \%$ 로 매우 낮았다. 단순히 배양만 할 경우 독소를 생산하는지 알 수 없어서 보균자와의 감별이 어렵 다[13]. 배양 시 선택배지보다는 발색배지를 사용하는 경우가 더 많았는데 $(75 \%, 15 / 20)$, 국내 한 연구에서도 발색배지의 유 용성을 제시한 바 있다[25]. 입원환자의 경우 일반세균보다 $C$. difficile 감염빈도가 훨씬 더 높으며 $[7,8,11]$, 독소검사의 민감 도가 낮으므로 이 균의 배양 및 독소 생성검사를 시행하는 것 이 필요해 보이지만, 혐기성 배양시설이 필요하므로 검사실 규 모가 작은 기관에서는 시행하기 어려운 제한점이 있다.

$\mathrm{VRE}$ 와 $\mathrm{CRE}$ 는 일반적인 대변배양검사라기보다는 의료기 관연관 감염예방을 위한 검사이므로, 여기서는 자세히 언급하 지 않는다. 두 가지 모두 상품화된 배지를 사용하는 기관이 대 부분이었다(자료 미제시).

항균제 감수성결과의 보고방법은 다양하였는데, CLSI 지침 대로[20] 하는 기관은 $69.1 \%$ (액체배지희석법 39기관, 디스크 확산법 8기관)였다. 모든 항균제에 대해서 보고한 후 코멘트에 CLSI 내용을 추가하는 기관은 $8.8 \%$ 였다. CLSI 지침에는 인 
Jung-Hyun Byun et al • Nationwide Survey of Stool Culture Methods

체 내 효과가 없는 항균제는 보고하지 않는 것이 바람직하다고 하였다 16-18]. 하지만 CLSI 지침대로 하는 것이 효율성 측면 에서는 문제가 있을 수 있다. 즉 우리가 보고하는 다른 균(장 내세균, 그람양성알균 등)을 모두 포함하면 보고하는 조건이 매우 다양하고 복잡해진다. 일일이 균종마다 차이를 두고 보고 하다 보면 보고할 때 실수할 가능성이 높다. Salmonella만 하 더라도 검체가 대변인지 혈액인지에 따라서 차이가 있고 대변 의 경우에도 필요에 따라서는 혈액에서 보고하는 항생제의 보 고가 필요한 경우가 있다. 또한 임상적으로 유용하지는 않지만 역학적인 목적으로 항균제 감수성결과를 비교할 경우가 많다. 이때 처음 결과를 입력해 놓지 않으면 차후 그 데이터를 이용 할 수 없기 때문에 CLSI 지침대로 시행할지 여부에 대해서는 추후 전문가 논의가 필요하다. 항균제에 의해 정상적인 그람음 성간균이 전혀 자라지 않는 경우에 그에 대한 내용을 보고하는 것이 좋겠고[18], 만약 포도알균, 녹농균 및 효모균이 순수하 게 혹은 우월적으로 자란 경우에도 이에 대해서 보고하는 것이 바람직하다[18]. 항균제를 사용하는 경우에 항균제에 의해 정 상적인 그람음성 장내세균이 억제되고 황색포도알균, 효모균, 녹농균이 순수하게 증식할 수 있으나 그 임상적 의의에 대해서 는 아직 명확하지 않으므로 이에 대한 추가적인 연구가 필요하 다. 본 조사에서도 일부 병원에서만 이들 균을 양성으로 보고 하고 있었다.

결론적으로, 대변의 그람염색이나 직접도말검사가 도움을 줄 수 있지만 그 효용성에 대해서는 논란의 여지가 있다. 따라 서 대변의 그람염색이나 직접도말검사에 의한 백혈구검사의 필요성에 대해서 추후 연구가 필요하다. 액체 증균배지를 반드 시 포함시키는 것이 좋고, 액체배지에 2-8시간 증균시킨 후 퇴 근 전에 $\mathrm{SS}$ 에 접종하고, 세균 억제효과가 적다고 알려진 XLD 나 $\mathrm{HE}$ 중 한 가지를 추가로 사용하는 것을 권장한다. 배양온 도와 배양시간은 큰 문제가 없어 보이며, 배양가스는 공기를 사용하는 것을 추천한다. 대변배양은 많은 검사업무 부하가 걸 리고 비용이 많이 드는 검사이므로, 이를 효율적으로 수행하기 위해 어떤 배지를 1 차로 사용할지, 한천배지를 추가할지, 수송 배지를 일상적으로 사용할지 등에 대한 추가적인 연구가 필요 하다. 배양이 까다로운 Campylobacter를 검출하기 위한 시설 을 구비하며, 혈변인 경우 반드시 E. coli O157 검사를 시행하 거나 외부로 의뢰하여 항균제 사용 여부를 판단하는데 도움을 주어야 한다. C. difficile 감염의 경우 효소면역법에 의한 독소 검사가 가능하므로, 검사실 규모가 작다면 굳이 배양까지 할 필요는 없다. 만약 $C$. difficile 배양을 시행한다면 독소검사를 추가하여야 보균자와 감별이 가능하다. 대변의 질(묽기)은 수 양변, 무른변, 고형변으로 구분하고, 점액성인지 혈변인지 추
가하여 기술하고, 고형변의 경우 배양하지 않는 것을 권장한다.

\section{감사의 글}

이 논문은 대한임상검사정도관리협회 2016년 학술연구비 지원에 의하여 이루어진 것이다(2016-13). 본 설문에 회신을 보내 주신 모든 분들께 깊은 감사를 드린다.

\section{REFERENCES}

1. DuPont HL. Clinical practice: bacterial diarrhea. N Engl J Med 2009;361:1560-9.

2. Kotloff KL, Nataro JP, Blackwelder WC, Nasrin D, Farag TH, Panchalingam S, et al. Burden and aetiology of diarrhoeal disease in infants and young children in developing countries (the Global Enteric Multicenter Study, GEMS): a prospective, case-control study. Lancet 2013;382:209-22.

3. Forbes BA, Sahm DF, Weissfeld AS. Study guide for Bailey \& Scott's diagnostic microbiology. 12th ed. St. Louis (MO): Mosby Inc., 2007.

4. The Korean Society of Infectious Diseases; Korean Society for Chemotherapy; The Korean Society of Clinical Microbiology. Clinical guideline for the diagnosis and treatment of gastrointestinal infections. Infect Chemother 2010;42:323-61.

5. Bowman RA, Bowman JM, Arrow SA, Riley TV. Selective criteria for the microbiological examination of faecal specimens. J Clin Pathol 1992;45:838-9.

6. Pawlowski SW, Warren CA, Guerrant R. Diagnosis and treatment of acute or persistent diarrhea. Gastroenterology 2009;136:1874-86.

7. Lee J, Kim J, Cho H, Oh K, Uh Y, Yoon KJ. Detection of bacterial and viral pathogens in stool specimens using multiplex PCR. J Lab Med Qual Assur 2015;37:141-7.

8. Lee S, Park YJ, Lee HK, Kim SY, Kim JY, Lee SY, et al. Detection of 13 enteric bacteria and 5 viruses causing acute infectious diarrhea using multiplex PCR from direct stool specimens. Ann Clin Microbiol 2013;16:33-8.

9. Binnicker MJ. Multiplex molecular panels for diagnosis of gastrointestinal infection: performance, result interpretation, and cost-effectiveness. J Clin Microbiol 2015; 


\section{Journal of LABORATORY MEDICINE and QUALITY ASSURANCE \\ Jung-Hyun Byun et al • Nationwide Survey of Stool Culture Methods}

$53: 3723-8$

10. Cho MC, Noh SA, Kim MN, Kim KM. Direct application of multiplex PCR on stool specimens for detection of enteropathogenic bacteria. Korean J Clin Microbiol 2010; 13:162-8.

11. Murray PR, Baron EJ, Jorgensen JH, Pfaller MA, Yolken RH. Manual of clinical microbiology. 7th ed. Washington (DC): American Society for Microbiology, 2005.

12. Fan K, Morris AJ, Reller LB. Application of rejection criteria for stool cultures for bacterial enteric pathogens. J Clin Microbiol 1993;31:2233-5.

13. Chong YS. Diagnostic microbiology. 5th ed. Seoul: Seoheung Press, 2014.

14. Harris JC, Dupont HL, Hornick RB. Fecal leukocytes in diarrheal illness. Ann Intern Med 1972;76:697-703.

15. Nicholson MR, Van Horn GT, Tang YW, Vinje J, Payne DC, Edwards KM, et al. Using multiplex molecular testing to determine the etiology of acute gastroenteritis in children. J Pediatr 2016;176:50-6.

16. Clinical and Laboratory Standards Institute. Performance standards for antimicrobial susceptibility test twentyfifth informational supplement. Wayne (PA): Clinical and Laboratory Standards Institute, 2016.

17. Korean Society of Laboratory Medicine. Laboratory medicine. 5th ed. Seoul: Medicalplus, 2014.
18. Leber AL. Clinical microbiology procedures handbook. 4th ed. Washington (DC): ASM Press, 2016.

19. Kim GT, Kim JC, Song HS. Stool cultures and antibiotic therapy in cases of acute diarrhea. J Korean Soc Emerg Med 2001;12:64-73.

20. Hatchette TF, Farina D. Infectious diarrhea: when to test and when to treat. CMAJ 2011;183:339-44.

21. Lee MA. Usefulness of selenite F enrichment broth for the isolation of Salmonella from stool. Korean J Clin Pathol 2000;20:184-7.

22. Ko EG, Kim CJ, Lee KE, Cho J, Moon YH. Comparison of isolation rate of the pathogenic microorganisms according to stool culture methods. Korean J Clin Microbiol 1998;1:57-62.

23. Song HJ, Shim KN, Jung SA, Choi HJ, Lee MA, Ryu KH, et al. Antibiotic-associated diarrhea: candidate organisms other than Clostridium difficile. Korean J Intern Med 2008;23:9-15.

24. Seo GS. Clostridium difficile infection: what's new? Intest Res 2013;11:1-13.

25. Yim JS, Hwang SM, Kim M, Lim HJ, Shin S, Chung HS, et al. Evaluation of a ChromID C. difficile agar for the isolation of Clostridium difficile. Korean J Clin Microbiol 2012;15:88-91. 


\section{세균성 위장관염 진단을 위한 2016년 대변배양 전국 실태조사} 변정현 - 오수인 ${ }^{2}$ 박현웅 ${ }^{2}$ 김선주 ${ }^{1}$ - 신정환 ${ }^{3}$

${ }^{1}$ 경상대학교 의과대학 진단검사의학교실, ${ }^{2}$ 창원경상대학교병원 진단검사의학과, ${ }^{3}$ 인제대학교 부산백병원 진단검사의학과

배경: 대변배양은 세균성 위장관염을 진단하는 데 필수적인 검사이다. 하지만 대변배양 검사방법이나 분리하고자 하는 세균은 검사기관마다 차이가 크다. 본 연구에서는 전국적 설문조사를 이용하여 우리 나라의 대변배양실태를 조사하였다.

방법: 대변배양에 대한 설문지를 진단검사의학과 전문의 98 명에게 이메일로 전송하였고, 대한임상검 사정도관리협회에 소속되어 있으면서 세균배양을 실시하는 301기관에 구글 프로그램을 이용하여 발 송하였다.

결과: 총 68 기관이 회신을 하였는데, 그람염색과 직접도말검사를 실시하는 비율은 각각 $73.5 \%$ 와 $64.7 \%$ 였다. 분자유전학적 방법을 사용하는 기관은 $32.4 \%$ 였다. 황색포도알균, 녹농균 및 효 모균이 우세하게 보이는 경우 이를 보고하는 기관은 각각 $17.6 \%, 8.8 \%, 7.4 \%$ 에 불과하였다. Campylobacter를 분리할 수 있는 기관은 $25.0 \%$ 에 불과하였고, Clostridium difficile은 $38.2 \%$ 에서 배양하고 있었다. Salmonella-Shigella가 분리되는 경우 Clinical and Laboratory Standard Institute 지침대로 보고하는 기관은 $69.1 \%$ 였고, $22.1 \%$ 는 검사한 모든 항균제 감수성결과를 보고 하고 있었으며, 나머지 8.8\%는 두 가지 방법을 조합하여 사용하였다.

결론: 설문조사결과 그람염색, 직접도말검사, 사용하는 배지종류, 분리하고자 하는 세균 및 항균제 감 수성결과 보고방법은 검사실마다 매우 다양하였다. 세균성 위장관염 환자에서 원인균 분리율을 높이 기 위해 표준화된 지침 마련이 필요하다.

(J Lab Med Qual Assur 2017;39:23-30)

교신저자: 김선주

우)52727 진주시 강남로 79 , 경상대학교 의과대학 진단검사의학교실

Tel: 055)214-3072, Fax: 055)214-3089, E-mail: sjkim8239@hanmail.net 